Science, Technology and Development 34 (2): 86-89, 2015

ISSN 0254-6418 / DOI: 10.3923/std.2015.86.89

(C) 2015 Pakistan Council for Science and Technology

\title{
Effect of Dipping in Sugar Solutions on Drying Behavior of Cantaloupe
}

\author{
Maazullah Khan, Shahid Akbar Khalil and Nizakat Bibi \\ Nuclear Institute for Food and Agriculture (NIFA), P.O. Box 446, Peshawar, Pakistan
}

\begin{abstract}
Drying of fruits, vegetables and other food materials is an energy intensive process (electrical drying) and time consuming (solar drying) process. Effect of dipping in various concentrations of sugar solutions on drying rate and drying time of cantaloupe. Cantaloupe (Cucumis melo L) was investigated as an energy and time efficient method for obtaining uniform was studied quality product. Cut, peeled and sulphited cantaloupe pieces were dipped in 25, 35 and $45 \%$ sugar solutions for 1,2 and $3 \mathrm{~h}$ with three replications in each treatment. Weight of the samples was recorded before placing in the oven $\left(60^{\circ} \mathrm{C}\right.$ and $1.1 \mathrm{~m} \mathrm{sec}^{-1}$ air velocity) and then at $4 \mathrm{~h}$ intervals continuously until there was no further weight loss and the product became leathery. The $\mathrm{pH}$ of the fresh fruit was 6.7. Highest total soluble solids $\left(12^{\circ}\right.$ brix $)$ were observed for the inner most whitish layer of the flesh while lowest ( $6^{\circ}$ brix) were observed for the green layer just beneath the skin indicating a gradient in TSS with in the same fruit. Sugar concentration and dipping time significantly ( $>>0.0001)$ affected moisture content of the samples and considerably reduced drying time. Combined effect of the two treatments was not significant ( $\mathrm{p}>0.4197)$. The moisture loss versus time curves indicated a linear trend with excellent fit $\left(\mathrm{R}^{2}>0.97\right)$ for all the treatments indicating a constant drying rate. The sugar concentration as well time of dipping affected both the initial moisture content as well the drying rate and consequently the drying time.
\end{abstract}

Key words: Cantaloupe, oven drying, drying rate, dipping, sugar solution

\section{INTRODUCTION}

Cantaloupe (Cucumis melo L) is a delicious and nutritious fruit grown in many countries around the world. The cantaloupe fruit consist of an outer thick skin (rind), the fruit flesh (edible portion)/fruit and seed. The flesh/fruit is used for human consumption and is good source of vitamins and minerals with many health benefits. Its vitamin $C$ content is $42 \mathrm{mg} / 100 \mathrm{~g}$ of fruit flesh. Important mineral constituents are calcium, magnesium, phosphorus and sodium. It is especially rich in potassium (309 mg/100 g of fruit flesh). Cantaloupe also contains zinc, selenium, iron, copper and manganese in trace quantities (USDA., 2007).

Cantaloupes are grown in the plan areas of the Khyber Pukhtoonkhwa, Punjab and Sindh provinces of Pakistan. Although its production data is not available, it is abundantly available during the harvesting season (May to August depending on variety) at very low prices. Due to its high moisture content (91\%), (Khan et al., 2009), soft internal tissue and large size resulting in very low bulk density, they are difficult to store in fresh form. Cantaloupe lose weight quickly and its internal tissues become soft thus causing a loss in value. In general, losses in fruits and vegetables are reported at about 25-40\% (Raja and Kokar, 1993) and even greater (Iqbal, 1996) due to lack of proper post harvest technologies for handling, storage and processing. In fresh form, cantaloupes can not be stored easily at room temperature. Storage of fresh fruits under refrigerated conditions may not be economically feasible due to the high cost of energy. A study (Khan et al., 2009) showed that oven (electrical) dried product quality was better than that of the solar dried product. However, the production cost was twice as much because of the cost of electrical energy. It was thus concluded from this study that electrical drying of cantaloupe was economically unfeasible. Results of Shahidi et al. (2005) indicated that sugar solution concentration $(40-70 \% \mathrm{w} / \mathrm{w})$ and time of immersion (0-4.5 h) had significant effects on solid gain, water loss and weight reduction, while sensory properties didn't change significantly. Efforts have been made (Mahmood et al., 2005, 2006; Khalil et al., 2012; Hanif et al., 2014) to develop solar drying systems as well as optimize drying conditions for various fruits and vegetables.

Drying/dehydration is one of the most cost effective preservation techniques for fruits and vegetables both in terms of initial investment and operating costs. Moisture content of the food is reduced under controlled conditions of air flow, temperature $\left(<70^{\circ} \mathrm{C}\right)$ and humidity $(<40 \%)$ to levels that inhibit microbial growth and enzymatic activity. Vegetables are blanched while fruits are mostly sulfured or soaked in salt or ascorbic acid solution before drying (Osaki and Gavranich, 1994). Although the use of sulfites has been banned by the Food and Drug

Corresponding Author: Maazullah Khan, Nuclear Institute for Food and Agriculture (NIFA), P.O. Box 446, Peshawar, Pakistan Tel: 009192-2964060-2, 03005834039 Fax: 009192-2964059 
Administration (FDA) on fresh fruits and vegetables, it is still used for color retention and inhibition of microbial activity in dried fruits and vegetables. Drying seems to be the most suitable option for preservation and value addition of cantaloupe. Although electrical drying is most efficient, the cost of energy is a limiting factor. Solar drying is less costly but takes a long time and the product often deteriorates during drying resulting in poor and non uniform product.

In order to be able to design an efficient drying system and achieve high quality products, moisture content was first reduced through osmotic dehydration and then dried in electrical oven. The objective of this study was to investigate drying rate of cantaloupe as affected by the time of dipping in sugar solutions of different concentrations.

\section{MATERIALS AND METHODS}

Fresh, ripe cantaloupes (Cucumis melo L) were obtained from the local market (Peshawar, Pakistan). They were washed, peeled and cut into slices of $3 \mathrm{~cm}$ length with stainless steel knives. The $\mathrm{pH}$ and Total Soluble Solids (TSS) of the fresh fruits were measured with $\mathrm{pH}$ meter and refractometer, respectively. The cantaloupe pieces were dipped in preservative $(0.2 \%$ potassium metabisulfite, $\mathrm{K}_{2} \mathrm{~S}_{2} \mathrm{O}_{5}$ with $57.6 \% \mathrm{SO}_{2}$ ) solution for $3 \mathrm{~min}$ to avoid discoloration during and after drying. The samples were dipped in 25, 35 and 45\% sugar solutions for 1, 2 and $3 \mathrm{~h}$ with three replications in each treatment. A completely randomized two-factorial experimental design was used. The samples were weighed and placed in a convection (electrical) dryer at $60^{\circ} \mathrm{C}$ and $0.6 \mathrm{~m} \mathrm{sec}^{-1}$ air velocity (measured with an anemometer (AVM-03, PROVA Instruments, Inc.). Humidity inside the dryer varied between 30 and $40 \%$. Weights of the samples were recorded initially at $2 \mathrm{~h}$ and then at $4 \mathrm{~h}$ intervals continuously until there was no further weight loss. Moisture content of the dried samples was determined using AOAC. (1984) method No. 14.004. The dry mass of each sample was measured.

Data analysis: The moisture content on dry basis (db) (g/g of dry matter) of all the samples was calculated from the recorded weight data and dry mass of the samples. In order to evaluate the significance of sugar concentration and time of dipping, the data was analyzed using General Linear Models Procedure (PROC GLM) SAS (1996). The means were separated using Duncan Multiple Range (DMR) test. Moisture removed (g/g dry matter) during each time interval was calculated by subtracting the final weight from initial weight for that interval and divided by the dry weight of the sample. The moisture loss was plotted against the drying time. Also drying rate ( $g$ of water removed per g dry matter per h) was calculated by dividing the moisture by the time interval and plotted against the moisture content.

\section{RESULTS AND DISCUSSION}

Color gradient within the same fruit from green layer just beneath the skin to yellow at the center was observed. Highest total soluble solids $\left(12^{\circ}\right.$ brix) were noted for the inner most whitish layer of the flesh while lowest ( $6^{\circ}$ brix) were observed for the green layer just beneath the skin. The $\mathrm{pH}$ of the fresh fruit was 6.7 indicating a neutral character with regards to acidity.

Statistical analysis of the initial moisture content just after the treatments revealed that sugar concentration and dipping time significantly $(p>0.0001)$ affected the moisture content of the samples (Table 1 ).

There is a clear trend of decreasing moisture content with increasing sugar concentration and dipping time. The mean moisture content decreased from 8.81-6.57 g/g dry matter) with sugar concentration increasing from $0-45 \%$, thus showing a decrease of $25.4 \%$. Similarly the mean moisture content decreased from 8.81-6.56 (g/g dry matter) for dipping time increasing from $0-3 \mathrm{~h}$ showing a decrease of $25.5 \%$, nearly the same as for concentration increase. These results reveal that longer dipping time will compensate for higher sugar concentration to achieve the same moisture level.

The trends followed by the moisture loss during oven drying for the various treatments are given in Fig. 1a-c and were fitted to a linear equation of the form:

$$
\mathrm{y}=\mathrm{a}+\mathrm{bx}
$$

where,

y : Moisture content (g/g of dry matter)

a : Intercept (initial moisture content g $\mathrm{H}_{2} \mathrm{O} / \mathrm{g}$ dry matter)

$\mathrm{b}$ : Slope of the line (drying rate, $\mathrm{g} \mathrm{h}^{-1}$ ). Negative sign indicates moisture loss

$\mathrm{x}$ : Drying time (h)

The intercept $\mathrm{a}$, slope $\mathrm{b}$ and $\mathrm{R}^{2}$ for the various treatments are given in Table 2 . The high $\mathrm{R}^{2}(>0.97)$ for all the treatments indicated a linear fit and thus a constant

\begin{tabular}{|c|c|c|c|c|c|}
\hline \multirow{2}{*}{$\begin{array}{l}\text { Sugar } \\
\text { concentration (\%) }\end{array}$} & \multicolumn{5}{|c|}{ Dipping time (h) } \\
\hline & 0 & 1 & 2 & 3 & Mean \\
\hline 0 & 8.81 & & & & $8.81^{\mathrm{a}}$ \\
\hline 25 & & 8.30 & 7.81 & 7.45 & $7.85^{\mathrm{b}}$ \\
\hline 35 & & 7.57 & 6.84 & 6.25 & $6.89^{c}$ \\
\hline 45 & & 7.17 & 6.53 & 6.00 & $6.57^{\mathrm{d}}$ \\
\hline Mean & $8.81^{\mathrm{a}}$ & $7.68^{\mathrm{b}}$ & $7.06^{c}$ & $6.56^{\mathrm{d}}$ & \\
\hline
\end{tabular}

Numbers followed by different alphabets are significantly different 
Table 2: Equations for moisture loss based from cantaloupe during oven drying

\begin{tabular}{|c|c|c|c|c|c|}
\hline \multirow[b]{2}{*}{ S. No } & \multicolumn{5}{|l|}{ Treatments } \\
\hline & $\begin{array}{l}\text { Sugar } \\
\text { concentration y (\%) }\end{array}$ & $\begin{array}{l}\text { Dipping } \\
\text { time (h) }\end{array}$ & A & $\mathrm{B}$ & $\mathrm{R}^{2}$ \\
\hline $\mathrm{C}$ & 0 & 0 & 8.98 & -0.237 & 0.99 \\
\hline 11 & 25 & 1 & 8.14 & -0.235 & 0.99 \\
\hline 12 & 25 & 2 & 7.41 & -0.203 & 0.99 \\
\hline 13 & 25 & 3 & 6.86 & -0.205 & 0.97 \\
\hline 21 & 35 & 1 & 6.86 & -0.218 & 0.98 \\
\hline 22 & 35 & 2 & 6.30 & -0.211 & 0.97 \\
\hline 23 & 35 & 3 & 6.11 & -0.188 & 0.99 \\
\hline 31 & 45 & 1 & 6.78 & -0.203 & 0.98 \\
\hline 32 & 45 & 2 & 6.08 & -0.181 & 0.97 \\
\hline 33 & 45 & 3 & 5.71 & -0.170 & 0.97 \\
\hline
\end{tabular}
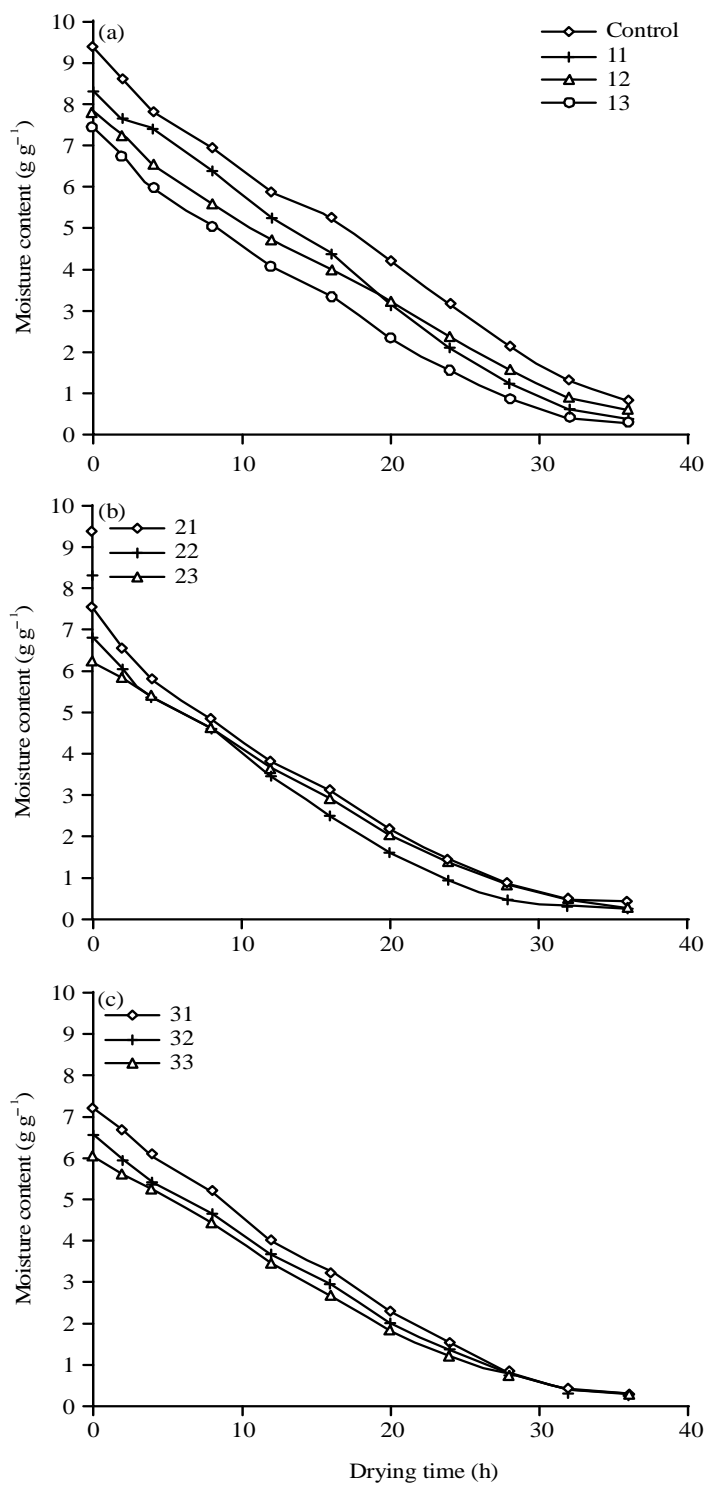

Fig. 1(a-c): Moisture loss from cantaloupe during drying in convection dryer at $60^{\circ} \mathrm{C}$ for various sugar concentrations drying rate. It can be observed that initial moisture content (a) and drying rate (b) varied with treatment. It can be seen from Table 2 that control samples had the highest drying rate $\left(0.237 \mathrm{~g} \mathrm{~h}^{-1}\right)$ while, the sample 33 (dipped in $45 \%$ sugar solution for $3 \mathrm{~h}$ ) had the lowest drying rate $\left(0.170 \mathrm{~g} \mathrm{~h}^{-1}\right)$. It can be inferred from this data that drying rate decreased with decrease in moisture content caused by osmotic dehydration. Although the drying rate remained constant over time for the same treatment, it varied for samples with different initial moisture contents resulting from the different treatments. These equations can be used for estimating drying time for a given treatment and thus designing of drying process.

Uddin et al. (2004), reported a significant effect of time of immersion and concentration of sucrose solution on water loss while studying mass exchange during osmotic dehydration of carrots. These results are in agreement with those of Shahidi et al. (2005) who reported that solution concentrations $(40-70 \% \mathrm{w} / \mathrm{w})$ and time of immersion (0-4.5 h) had significant effects on solid gain, water loss and weight reduction during osmotic dehydration of cantaloupes. A similar phenomena has been reported by Lombard et al. (2008), for pine apple. Kowalska and Lenart (2001) reported that osmotic dehydration of apple slices in 51.5\% sugar solution for 30 min resulted in $48 \%$ reduction in moisture content. The significance of these results is that moisture content in a product can be reduced by manipulating either the dipping time or sugar concentration depending upon process requirements.

\section{REFERENCES}

AOAC., 1984. Official Methods of Analysis. 13th Edn., Association of Official Analytical Chemists, Washington, DC., USA., pp: 768-800.

Hanif, M., M.K. Khattak, Masood-ur-Rahman, M. Khan, M. Amin and M. Ramzan, 2014. Performance evaluation of a flat plate solar collector as a drier for chillies and tomatoes. Sci. Technol. Dev., 33: 63-67.

Iqbal, M., 1996. Type and extent of post-harvest losses in horticultural commodities in Pakistan. Proceedings of the National Conference on Post Harvest Technology of Horticultural Commodities, September 10-12, 1996, Quetta, pp: 32-42.

Khalil, M.H., M.A. Khan, M. Ramzan, M.U. Rahman, M.K.M. Amin and A. Ali, 2012. Drying of apricots using a proficient dish type solar air heater. World Applied Sci. J., 18: 1102-1106.

Khan, M., S.A. Khalil and A.B. Khattak, 2009. Solar and electrical drying of cantaloupes (Cucumis melo L.): Quality attributes and economic feasibility. Adv. Food Sci., 31: 176-178. 
Kowalska, H. and A. Lenart, 2001. Mass exchange during osmotic pretreatment of vegetables. J. Food Eng., 49: 137-140.

Lombard, G.E., J.C. Oliveira, P. Fito and A. Andres, 2008. Osmotic dehydration of pineapple as a pre-treatment for further drying. J. Food Eng., 85: 277-284.

Mahmood, Z., A. Malik, M. Khan, M. Asif and A. Masood, 2006. Performance evaluation of solar dryers for drying onions in NWFP. Sarhad J. Agric., 22: 1-5.

Mahmood, Z., M. Khan, A. Masood and M. Asif, 2005. Design and development of a Gable type solar dryer for drying fruit and vegetables. Sarhad J. Agric., 21: 525-529.

Osaki, S. and C. Gavranich, 1994. Dehydration pre-treatments. Cooperative Extension, University of California, Aubum, CA.
Raja, M.B. and K.M. Khokhar, 1993. Post harvest horticulture technology and its future prospects. Proceedings of the 1st International Horticulture Seminar, January 10-12, 1992, Pakistan Research Council Islamabad, pp: 265-277.

SAS., 1996. SAS/STAT Guide For Personal Computers. Version 6.12, SAS Institute, Cary, NC.

Shahidi, F., F. Amidi, M. Mohebbi and A. Ganjloo, 2005. Osmotic dehydration of cantaloupe: Influences of time and concentration. Acta Horticulturae, 731: 129-134.

USDA., 2007. National nutrient database for standard reference. Release No 20, Melons, Cantaloupe, Raw, NDB No: 09181, United States Department of Agriculture (USDA), USA.

Uddin, M.B., P. Ainsworth and S. Ibanoglu, 2004. Evaluation of mass exchange during osmotic dehydration of carrots using response surface methodology. J. Food Eng., 65: 473-477. 